\section{\$150M for Stanford center}

The man who founded Netscape has donated $\$ 150$ million to Stanford University to create a new interdisciplinary biomedical center to look for disease cures and build new medical devices. The "Bio-X" center will be formally known as the James H. Clark Center for Biomedical Engineering and Sciences, after the former Stanford engineering professor who also founded Silicon Graphics, Healtheon, and myCFO. Clark made the donation-Stanford's largest single gift everwith proceeds of the sale of his share of the recent $\$ 10$ billion acquisition of Netscape by America Online. Clark said he was donating the money to develop new technologies such as prosthetic devices or artificial organs that exist at the boundary of science, engineering, and medicine. $\mathrm{He}$ is especially interested in neuroinformatics, or how people process data. "Computer technology has become more miniature and faster, and so increasingly I think we'll see it become an extension of humans and other living things," Clark said.

\section{Japan patent directives}

The Japanese Patent Office (JPO; Tokyo) has released its first directives on human gene patents, outlining the patentability of expressed sequence tags (ESTs), full-length cDNA clones, and single-nucleotide polymorphisms. The directives specify that partial DNA sequences and genes cannot be patented without demonstrated utility, and are in line with the position taken by the US Patent and Trademark Office (Washington, DC) and the European Patent Office (Munich) on human gene patents.

The new directives could be bad news for Helix Research Institute (Chiba Prefecture), which filed patent applications on more than 6,000 full-length human cDNA clones in July. Helix, a genomics company jointly funded by the Ministry of International Trade and Industry (MITI; Tokyo) and 10 Japanese pharmaceutical companies, applied for three patents-two for cDNA clones (sets of 200 and 850) believed to correspond to genes that express membrane and secretory proteins, and one for about 5,000 cDNA clones of unknown function. Critics say Helix's patent applications are unlikely to be approved as the utility of the invention is not clear.

\section{Sequencing, patenting surge}

Celera Genomics (Rockville, MD) announced in October that it has sequenced some 1.2 billion bp (about a third) of the human genome and that this information was being released to private subscribers. Celera also announced that it would file provisional patent applications for 6,500 genome-related discoveries but would postpone deciding which of those applications to pursue fully. Several other companies, including Human Genome Sciences (Rockville, MD) and Incyte (Palo Alto, CA), are also sequencing human gene segments and have been filing patent appli- cations to cover resulting sequence discoveries. These ventures could thwart a bid in the opposite direction-marked by toplevel discussions between British Prime Minister Tony Blair and US President Bill Clinton that comes with agreement from members of the publicly funded International Consortium-to develop a no-patenting agreement.

\section{Agbiotech outreach boosted}

Officials at the USDA and the FDA are stepping up public outreach efforts on food and agbiotech issues. For example, at the end of October, the USDA inaugurated a website (www.aphis.usda.gov/biotechnology/) dedicated to agricultural biotechnology issues. The site offers many useful links, including sites maintained by several other agencies within the department, food issues related FDA sites, and documents dealing with agricultural trade issues on the Internet site maintained by the Office of US Trade Representative (Washington, DC). Meanwhile, FDA officials announced that the agency would convene three public meetings to address issues regarding foods derived from GM plants, inviting views from the public on whether agency policies and procedures for dealing with these issues need to be modified. Those meetings were scheduled for November 18 in Chicago, IL, November 30 in Washington, DC, and December 13 in Oakland CA; the agency will accept written comments on this topic until January 13, 2000.

\title{
Research collaborations
}

$\begin{array}{llr}\text { Company } 1 & \text { Company } 2 & \text { \$ Million } \\ \begin{array}{l}\text { Millennium Predictive Medicine } \\ \text { (MPM; Cambridge, MA) }\end{array} & \begin{array}{l}\text { Bristol Myers Squibb } \\ \text { (BMS; Princeton, NJ) }\end{array} & 32 \\ \begin{array}{l}\text { Schering-Plough } \\ \text { (Madison, NJ) }\end{array} & \begin{array}{l}\text { AtheroGenics } \\ \text { (Atlanta, GA) }\end{array} \\ \begin{array}{l}\text { Athero- } \\ \text { alties, }\end{array} & 180 \\ \begin{array}{l}\text { Rigel } \\ \text { (S. San Francisco, CA) }\end{array} & \begin{array}{l}\text { Novartis Pharma AG } \\ \text { (Basel, Switzerland) }\end{array}\end{array}$

Bioreason

(Santa Fe, NM)
Biacore
(Uppsala, Sweden)
Details

A five-year pharmacogenomics agreement to identify and validate oncology clinical markers that can help predict patient responses to BMS cancer treatments and develop new therapies. MPM will receive \$32 million in research funding and license fees, in addition to milestones and royalties.

80 An agreement to develop and commercialize AtheroGenic's orally available lead compound, AGI-1067-the first composite vascular protectant-for the treatment and prevention of re-stenosis. Schering, which could pay

Genics $\$ 180$ million in upfront fees and milestones, in addition to roy-

has worldwide rights to develop and market AtheroGenic's v-protectants.

A five-year drug discovery collaboration in the area of autoimmune diseases such as lupus and rheumatoid arthritis. Rigel's functional genomics technology will be used to identify and validate small-molecule drug targets involved in B-cell function. Rigel receives an undisclosed cash payment, milestones, and royalties on resulting vaccines, diagnostics, and therapeutics; Novartis has worldwide rights to develop and market the products.

A drug discovery collaboration under which Biacore has made an equity investment in Bioreason. The companies aim to develop instruments, novel software, validated assays, analyses, and predictive models to help pharmaceutical companies reduce drug development time and cost. 